MINERALOGIA POLONICA

DOI 10.2478/v10002-007-0026-5

PL ISSN 0032-6267

Vol. 38, No 2, 2007

Ksenia MOCHNACKA ${ }^{1}$, Teresa OBERC-DZIEDZIC ${ }^{2}$, Wojciech MAYER ${ }^{1}$, Adam PIECZKA ${ }^{1}$, Michat GÓRALSKI ${ }^{3}$

\title{
OCCURRENCE OF SULPHIDES IN SOWIA DOLINA NEAR KARPACZ (SW POLAND) - AN EXAMPLE OF ORE MINERALIZATION IN THE CONTACT AUREOLE OF THE KARKONOSZE GRANITE
}

\author{
Received November 03, 2007; accepted December 18, 2007
}

Abstract. The authors studied the poorly-known, uneconomic sulphide mineralization site in Sowia Dolina near Karpacz. Host rocks are hornfelses of the Velká Úpa schist series, which belongs to the Izera-Kowary Unit. Ore minerals assemblage includes: pyrrhotite, pyrite, chalcopyrite, arsenopyrite, sphalerite, galena and marcasite, accompanied by ilmenite and rutile. The oldest sulphide is high-temperature pyrrhotite crystallized at about $600^{\circ} \mathrm{C}$, which is in good agreement with the temperature range of contact metamorphic conditions, revealed by muscovitessillimanite transformation. Low-temperature pyrrhotite and other sulphides formed at about $390^{\circ} \mathrm{C}$ (arsenopyrite geothermometer) down to $265^{\circ} \mathrm{C}$ (pyrrhotite geothermometer), whereas fluid inclusions studies of vein quartz demonstrated the temperature range $380-150^{\circ} \mathrm{C}$. Mineralization in Sowia Dolina is similar to other ore hydrothermal deposits known from the proximal or distal contact zone of the Karkonosze granite.

Key-words: the West Sudetes, Karkonosze granite, metamorphic envelope, Izera-Kowary Unit, Sowia Dolina, contact aureole, ore mineralization

\section{INTRODUCTION}

Little is known about sulphide mineralization in Sowia Dolina (Owl Valley). The very early but rather enigmatic information comes from Traube (1888) who mentioned an arsenopyrite occurrence in samples from an adit located in Wilcza Poręba (an area at the entrance to Sowia Dolina). Much better localized was an observation of Petrascheck

1 AGH-University of Science and Technology, Faculty of Geology, Geophysics and Environment Protection, al. Mickiewicza 30, 30-059 Kraków, Poland; e-mail: kmoch@geol.agh.edu.pl

2 University of Wrocław, Institute of Geological Sciences, Plac M. Borna 9, 50-204 Wrocław, Poland.

3 AGH-University of Science and Technology, Faculty of Management, al. Mickiewicza 30, 30-059 Kraków, Poland. 
(1933) who described a steep $\left(70^{\circ}\right)$, N-S striking quartz vein with pyrrhotite, chalcopyrite and pyrite in mica schists from Sowia Dolina. This vein followed the fracture system of the Karkonosze granite and was genetically related to the vein system of the granite. Hoehne (1952) mentioned samples from a Wagner adit located in Sowia Dolina where magnetite - pyrite - pyrrhotite - chalcopyrite - sphalerite - galena paragenesis was identified. Unfortunately, detailed localization of this adit is impossible.

Recently, Muszer (2005) identified chalcopyrite, pyrrhotite and pyrite in Sowia Dolina, and Piestrzyński (2005), reporting on historical mining operations in the Karpacz area, mentioned also galena as a member of the sulphide assemblage.

Traces of mineral exploration and mining operations are well visible in the western slope of the Płomnica stream valley called Sowia Dolina. The authors found four adits, the lowest located immediately above the stream bed, the remaining three cut into the steep valley slope. The lowest adit is inaccessible, the second adit, located about 50 meters upslope, is in perfect conditions but being inhabited by bats is closed for environmental reasons. The remaining two adits are hardly accessible due to roof collapse and intensive mine drainage.

The Sowia Dolina site is situated in the close contact aureole of the Karkonosze granite. The aim of this paper is to describe ore mineralization in relation to contact metamorphism and hydrothermal processes generated by the intrusion.

\section{GEOLOGICAL SETTING}

The Karkonosze-Izera Massif (KIM) is located in the West Sudetes and includes the Karkonosze granite intrusion enclosed within the Neoproterozoic-Paleozoic metamorphic envelope. The granite intrusion located in the center of the KIM separates the northern part of the metamorphic envelope, called the Izera Complex (IC), from the eastern part of the envelope, which embraces the Rudawy Janowickie Range and the Lasocki Range, and from the Southern Karkonosze complex.

The Karkonosze granite was dated with the $\mathrm{Rb}-\mathrm{Sr}$ whole rock isochrone method at $328 \pm 12 \mathrm{Ma}$ ("central" porphyritic granite) and 309 $\pm 3 \mathrm{Ma}$ ("ridge" equigranular granite) (Duthou et al. 1991; Pin et al. 1987), whereas $\mathrm{Pb} / \mathrm{Pb}$ and $\mathrm{U} / \mathrm{Pb}$ zircon datings yielded ages of $304 \pm 14 \mathrm{Ma}$ (Kröner et al. 1994) and 314 $\pm 3.3 \mathrm{Ma}$ and 318.5 $\pm 3.7 \mathrm{Ma}$ for granites of the NE part of the pluton (Machowiak, Armstrong 2007).

Mazur and Aleksandrowski (2001) interpreted the metamorphic envelope of the Karkonosze granite as four structural units (Fig. 1):

(1) the Izera-Kowary Unit (IKU),

(2) the Ješted Unit (JU),

(3) the Southern Karkonosze Unit (SKU),

(4) the Leszczyniec Unit (LU).

The Sowia Dolina area is located within the Izera-Kowary Unit.

The Izera-Kowary Unit is composed of various textural types of the Izera gneisses on the northern flank, and their equivalents - the Kowary and the Karkonosze gneisses on the southeastern and southern sides of the KIM (Fig. 1). The Izera gneisses enclose 


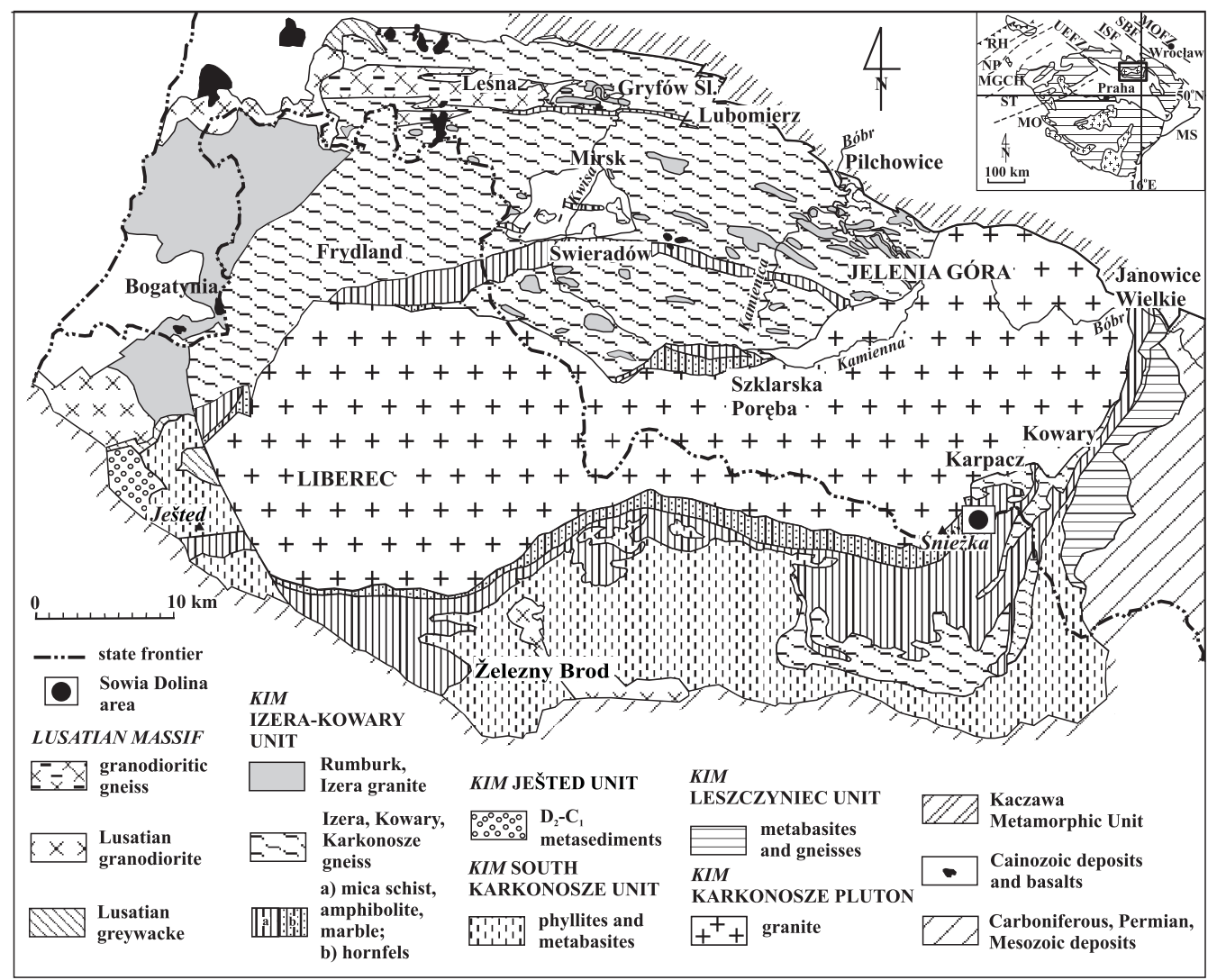

Fig. 1. Geological sketch map of the Karkonosze-Izera Massif (compiled on the basis of Chaloupský 1989, Mazur 1995, Mazur and Aleksandrowski 2001, Oberc-Dziedzic 2003). KIM - Karkonosze-Izera Massif. Inset map: EFZ - Elbe Fault Zone, ISF - Intra-Sudetic Fault, MGH - Mid-German High,

MO - Moldanubian Zone, MS - Moravo-Silesian Zone, NP - Northern Phyllite Zone, OFZ - Odra Fault Zone, RH - Rhenohercynian Zone, SBF - Sudetic Boundary Fault, SX - Saxothuringian Zone,

TB - Teplá-Barrandian Zone. Rectangle shows the position of the KIM in the Bohemian Massif

lenses of coarse-grained, porphyritic granites, the so-called Izera or Rumburk granites, considered as remnants of undeformed granitic protoliths of the coarse-grained gneisses. The granitoid protoliths of the Izera gneisses were dated by various methods at 515-480 Ma (Borkowska et al. 1980; Korytowski et al. 1993; Kröner et al. 2001; Oliver et al. 1993). The Kowary gneiss and the Karkonosze gneiss are of the same age, dated at around 492-481 Ma (U-Pb ages, Oliver et al. 1993) and 501.5 $\pm 1.1-503.2 \pm 1 \mathrm{Ma}$ $\left({ }^{207} \mathrm{~Pb} /{ }^{206} \mathrm{~Pb}\right.$ mean ages, Kröner et al. 2001).

The Izera, Kowary and Karkonosze gneisses are accompanied by the Velká Úpa Group schist series, about 1000 meters thick, distinguished by Chaloupský (1965) in the southern part of the IKU. The lower part of the Velká Úpa Group is a monotonous succession of grey, muscovite-albite schists with intercalations of albite-epidote amphibolites, amphibolites and quartzites. The upper part comprises greenish-grey, chlorite-muscovite-albite schists. Both part are separated by a lithologically diversfied 
transitional zone composed of mica schists with quartzites, erlanes, crystalline limestones, stripped amphibolites, felsitic metavolcanics, chlorite and graphite schists. The schists exposed in the eastern part of the IKU correspond to a variegated member of the Velká Úpa Group (Fig. 1, Mazur, Aleksandrowski 2001). Three schist belts embedded now in the Izera gneisses, each up to several hundred meters thick (Fig. 1), are considered to be an equivalent of the Velká Úpa Group in the northern part of the IKU (Chaloupský 1989). The schist used to be interpreted as the metamorphic envelope of ca 500 Ma granitoid protoliths of the Izera gneisses (Żelaźniewicz et al. 2003). The northern contacts of the schist belts are tectonic, whereas the southern contacts are accompanied by leucogranites interpreted as a marginal facies of the Izera granites (Berg 1923) or as products of leucocratization and alkaline metasomatosis of granites and gneisses (Kozłowski 1974).

The Izera-Kowary Unit experienced progressive MP-MT metamorphism, up to the low amphibolite facies conditions, locally overprinted by contact metamorphism caused by the Karkonosze intrusion (Kryza, Mazur 1995).

Southward and eastward the IKU plunges beneath the Southern Karkonosze and the Leszczyniec units, respectively.

\section{MATERIALS AND METHODS}

About 50 samples of host-rocks and ores were collected, mostly from a large dump beneath the second adit, for petrographic, mineralogical and geochemical studies. A few samples were taken from the valley bottom at the entrances to the lowest adit. Detailed microscopic observations were carried out on 42 thin sections under the transmitted light and 65 polished sections examined under the reflected light.

Chemical composition of minerals was analyzed with a CAMECA SX 100 microprobe analyser at the Electron Microprobe Laboratory, University of Warsaw, operating at acceleration voltage $15 \mathrm{kV}$, beam current of $10 \mathrm{nA}$ for plagioclase and mica analyses and $20 \mathrm{nA}$ for other minerals at counting time $20 \mathrm{~s}$ and background time $10 \mathrm{~s}$. The raw data were corrected with the ZAF procedure contained in the PAP software supplied by the CAMECA. The following standards, analytical lines and crystals were used: $\mathrm{Na}$ - albite $(K \alpha, \mathrm{TAP}), \mathrm{Mg}$ - diopside $(\mathrm{K} \alpha, \mathrm{TAP}), \mathrm{Al}$ - orthoclase $(\mathrm{K} \alpha, \mathrm{TAP}), \mathrm{Si}-$ diopside $(\mathrm{K} \alpha$, TAP), $\mathrm{S}$ - sphalerite $(\mathrm{K} \alpha, \mathrm{PET}), \mathrm{K}$ - orthoclase $(\mathrm{K} \alpha, \mathrm{PET}), \mathrm{Ca}$ - diopside $(\mathrm{K} \alpha, \mathrm{PET})$, $\mathrm{Ti}$ - rutile $(\mathrm{K} \alpha, \mathrm{PET}), \mathrm{V}$ - metallic $\mathrm{V}(\mathrm{K} \alpha, \mathrm{LIF}), \mathrm{Cr}-\mathrm{Cr}_{2} \mathrm{O}_{3}(\mathrm{~K} \alpha, \mathrm{PET}), \mathrm{Mn}$ - rhodonite $(\mathrm{K} \alpha, \mathrm{LIF}), \mathrm{Fe}-$ haematite $(\mathrm{K} \alpha, \mathrm{LIF}), \mathrm{Co}-$ metallic $\mathrm{Co}(\mathrm{K} \alpha, \mathrm{LIF}), \mathrm{Ni}-\mathrm{NiO}(\mathrm{K} \alpha, \mathrm{LIF})$,

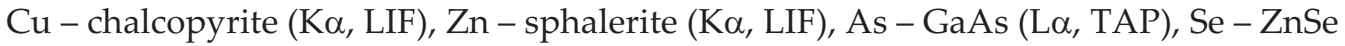
(L $\alpha, \mathrm{TAP}), \mathrm{Zr}$ - zircon (L $\alpha\langle, \mathrm{PET}), \mathrm{Nb}-\mathrm{LiNbO}_{3}(\mathrm{~L} \alpha, \mathrm{PET}), \mathrm{Ag}-$ metallic Ag (L $\left.\alpha, \mathrm{PET}\right)$, $\mathrm{Cd}-\mathrm{CdS}$ (L $\alpha, \mathrm{PET}), \mathrm{In}$ - InAs (L $\alpha, \mathrm{PET}), \mathrm{Sn}$ - cassiterite (L $\alpha, \mathrm{PET}), \mathrm{Sb}-\mathrm{InSb}(\mathrm{L} \alpha, \mathrm{PET})$, $\mathrm{Te}-\mathrm{PbTe}(\mathrm{L} \alpha, \mathrm{LIF}), \mathrm{Ta}$ - tantalite $(\mathrm{M} \alpha, \mathrm{TAP}), \mathrm{W}$ - scheelite $(\mathrm{M} \alpha, \mathrm{TAP}), \mathrm{Pb}$ - galena $(\mathrm{M} \alpha, \mathrm{PET}), \mathrm{Bi}-\mathrm{Bi}_{2} \mathrm{Te}_{3}(\mathrm{M} \alpha, \mathrm{PET}), \mathrm{Th}-\mathrm{ThO}_{2}(\mathrm{M} \alpha, \mathrm{PET})$ and $\mathrm{U}-\mathrm{UO}_{2}(\mathrm{M} \beta, \mathrm{PET})$.

Thermochemical conditions of the formation of ore minerals were determined from pyrrhotite, arsenopyrite and sphalerite chemical compositions analysed with the electron microprobe and supported by textural relationships between these minerals 
and the coexisting phases. The compositions of arsenopyrite crystals were drawn onto the sulphur fugacity $\left(\log f S_{2}\right)$ vs. temperature $(\mathrm{T})$ diagram for the Fe-As-S system (see Kretschmar, Scott 1976, modified by Sharp et al. 1985). Limitations of the arsenopyrite geothermometer, resulting from common inhomogenity of arsenopyrite crystals (Kerestedjian 1997), were taken into account. According to Sharp et al. (1985), the impact of pressure on arsenopyrite composition buffered by pyrrhotite and pyrite is insignificant in low-pressure hydrothermal deposits, and was ignored as such. Additionally, $\mathrm{N}_{\mathrm{FeS}}$ isopleths of FeS mole fraction in the FeS-S $\mathrm{S}_{2}$ system (Toulmin, Barton 1964) and concentration lines of FeS content (mole \%) in sphalerite (Barton, Toulmin 1966; Scott 1983) were marked in the Fe-As-S diagram.

Fluid inclusion studies were carried out on vein quartz collected from the main waste dump. Double-polished thin sections $200 \mathrm{~nm}$-thick were prepared. Observations were made at a Linkam THMS 600 heating-freezing stage attached to a Nikon Eclipse E6000 microscope and supplied with a TMS 93 module and a Linkam LNP pump. Images were recorded with an Ikegami video camera and a Linkam VTO 232 video panel. Observations were carried out with 50X and 100X lenses.

The stage was calibrated before measurements using a special thin section containing inclusions with pure $\mathrm{CO}_{2}$. Sections were abruptly freezed (in order to avoid the formation of metastable phases) down to the temperature $-120^{\circ} \mathrm{C}$, occasionally to $-198^{\circ} \mathrm{C}$, in order to reveal the presence of gases other than carbon dioxide. Heating rates were: $5-10^{\circ} \mathrm{C} / \mathrm{min}$ up to the room temperature (reduced to $0.5^{\circ} \mathrm{C}$ close to phase transformation points), then $20^{\circ} \mathrm{C} / \mathrm{min}$ to $100^{\circ} \mathrm{C}$, and 5 to $10^{\circ} \mathrm{C} / \mathrm{min}$ for higher temperatures. The accuracy of measurement for low temperatures was $0.1-0.2^{\circ} \mathrm{C}$. Analyses were carried out at the Department of Mineral Deposits and Mining Geology, Faculty of Geology, Geophysics \& Environment Protection, AGH-University of Science and Technology in Kraków.

\section{PETROLOGY OF HORNFELSES FROM THE SOWIA DOLINA}

Hornfelses from the Sowia Dolina are, in fact, the schists of the Velká Úpa Group thermally metamorhposed at the southern contact of the Karkonosze granite. The schists belong to the southern envelope of the granite. In the Polish part of the Sudetes these rocks crop out east of the Śnieżka Peak. In comparison to the hornfelses of the Szklarska Poręba schist belt, the Sowia Dolina hornfelses show well-preserved foliation and lineation.

Three spatially oriented thin sections from the Sowia Dolina hornfels and a single thin section from the hornfels-aplite contact were prepared. Older, pre-contact metamorphic components of the hornfelses are quartz domains and muscovite domains, which form bulk of the rocks. In the muscovite domains, older, small flakes are oriented mostly parallelly to the domain boundaries, but younger, large muscovite flakes are oblique to the domain boundaries. Rare, brownish, randomly arranged biotite flakes accompany the muscovite domains.

Contact metamorphic processes are documented by polygonal contours of quartz grains hosted in the quartz domains. In the muscovite domains, decomposition of both 
muscovite generations into thread-like crystals resembling the fibrolithic variety of sillimanite is common. However, the decomposition products show the interference colours typical of muscovite (Fig. 2). It suggests that either muscovite decomposition has not been completed or that transformation of sillimanite to muscovite proceeded immediately after formation of the former. If sillimanite formed from muscovite in the presence of quartz, the following reaction must have taken place:

$$
\text { muscovite }+ \text { quartz }=\text { sillimanite }+\mathrm{K} \text {-feldspar }+\mathrm{H}_{2} \mathrm{O}
$$

This reaction suggests the beginning of high-grade metamorphic conditions at the temperature $580^{\circ} \mathrm{C}$ at $1 \mathrm{~kb}$ and $660^{\circ}$ at $3 \mathrm{~kb}$ (Winkler 1979).

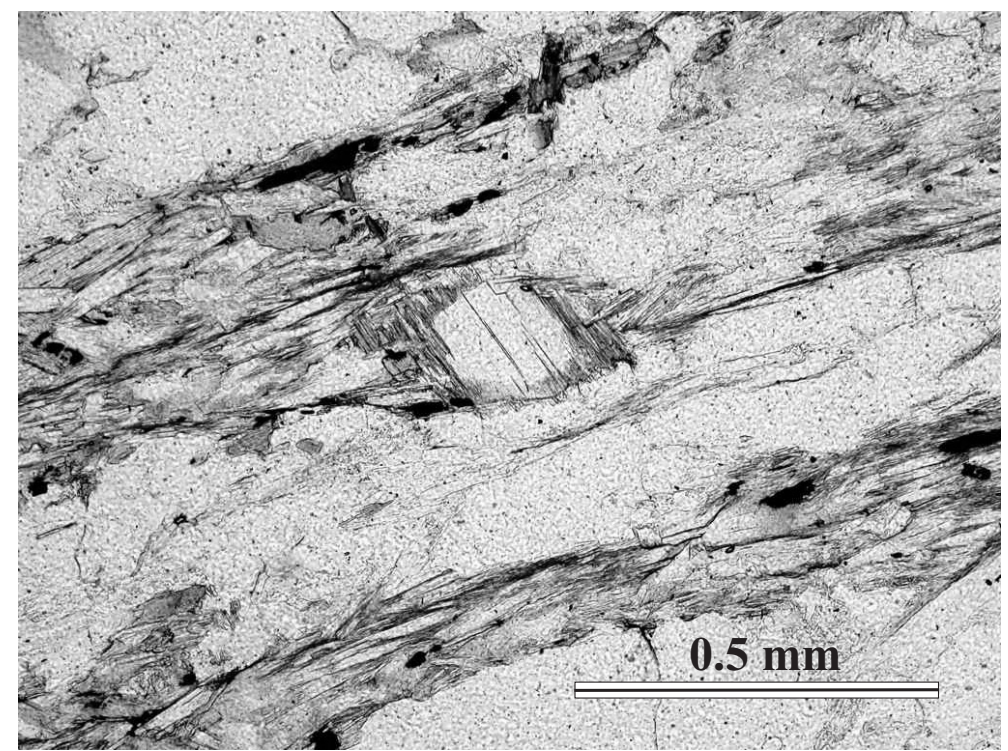

Fig. 2. Older, "transversal" muscovite transformed into fibrolite in hornfels. Plane polarized light

Contact metamorphism was also responsible for crystallization of andalusite and cordierite. Andalusite forms irregular crystals showing spotty, pink pleochroism, whereas cordierite accompanying the muscovite domains is completely transformed into pinite. Presumably, cordierite forms also larger, unpinitized crystals with abundant dark pigment. Contact metamorphic processes are probably responsible also for the formation of muscovite-biotite-plagioclase-opaque pseudomorphs after an unidentified mineral (garnet? Fig. 3). In such assemblages muscovite also shows traces of transformation into sillimanite. Hornfelses contain small amounts of plagioclases and K-feldspar. Opaque minerals occur as elongated grains arranged parallel to the foliation.

Aplite cutting the hornfels is pink, of random structure and fine-, equicrystalline texture. Main components are quartz, plagioclase, K-feldspar, muscovite and small amounts of chloritized biotite. Common are disseminated opaque minerals, $2-5 \mathrm{~mm}$ in 


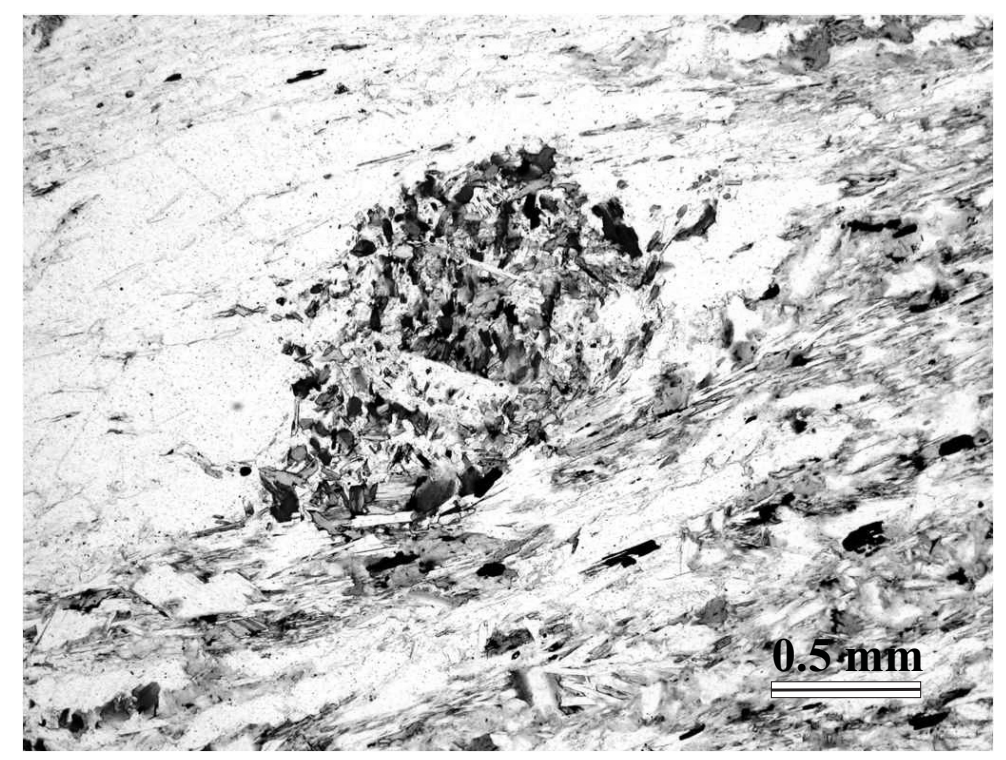

Fig. 3. Pseudomorph after garnet composed of muscovite, biotite, plagioclase and opaque minerals in hornfels. Plane polarized light

diameter, forming oriented intergrowths with quartz (Fig. 4). In some places, penetrations of quartz and, possibly, also albite and K-feldspar were observed (Fig. 5). Such assemblages are older than the ore minerals+quartz paragenesis. The thread-like K-feldspar crystals embedded within quartz crystals are other effects of the penetration. The penetrations presumably originated from a residual melt.

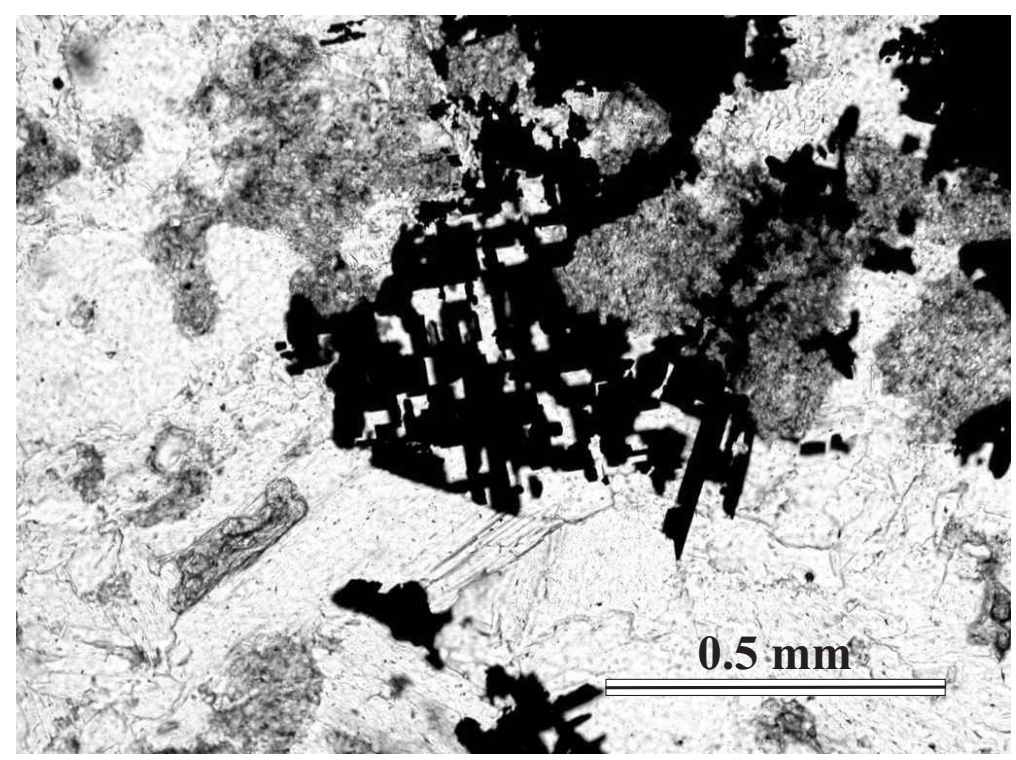

Fig. 4. Oriented intergrowths of quartz and opaque minerals in aplite. Plane polarized light 


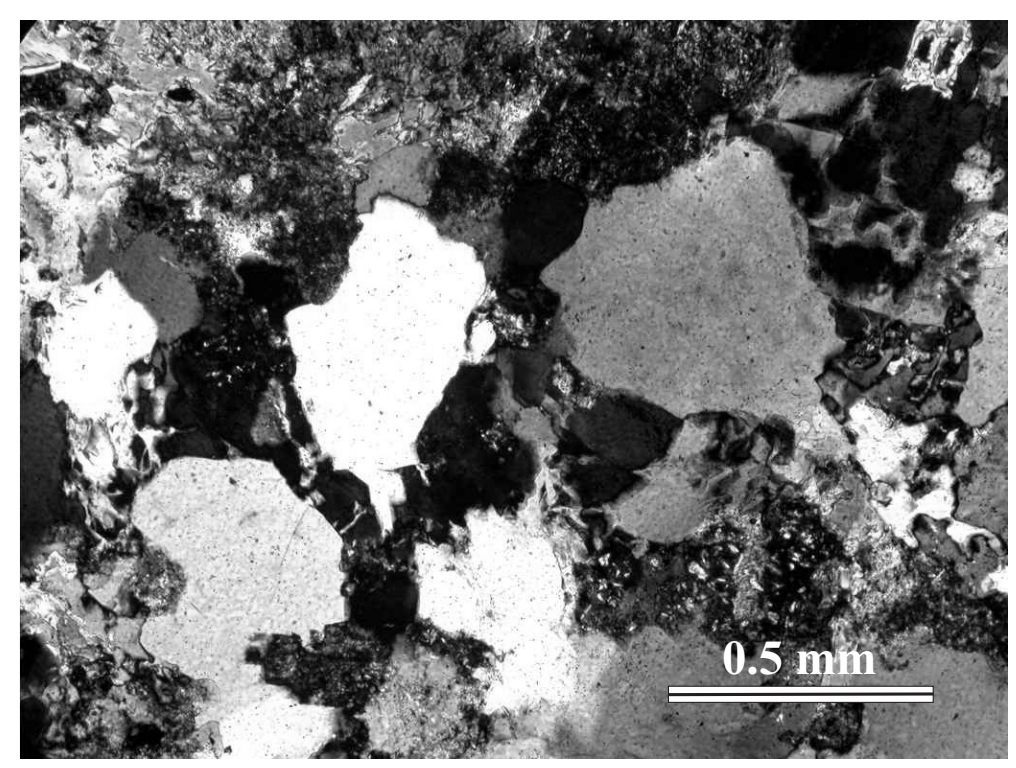

Fig. 5. Thread-like tangle of quartz, albite and K-feldspar in aplite. Crossed polars

\section{ORE MINERALIZATION}

The richest accumulations of ore minerals were found in hornfelses abundant in quartz and often cut by quartz-feldspar veinlets. Dominant ore mineral is pyrrhotite, only in a few samples pyrite prevails. Both sulphides form macroscopically visible, massive, several-centimeter thick accumulations (Fig. 6), veinlets and disseminated structures. Other ore minerals: chalcopyrite, galena, sphalerite, arsenopyrite, bornite, marcasite and Ti minerals occur in lesser amounts as disseminated grains or aggregates in veinlets (Fig. 6). Minute grains of monazite and xenotime were also found.

Pyrrhotite forms massive accumulations, disseminated aggregates and veinlets. Massive structures are arranged concordantly with the foliation of the host-rocks (Fig. 6). Usually, such accumulations contain abundant relics of hosting hornfelses, up to $1 \mathrm{~cm}$ across, showing evidence of metasomatic replacement of quartz and other rock-forming minerals by pyrrhotite. Disseminated pyrrhotite forms minute (a few millimeters long) lenses or nebulitic accumulations of small crystals. Veinlets, more than $5 \mathrm{~cm}$ long and up to $4 \mathrm{~mm}$ thick, are filled with pyrrhotite aggregates accompanied by quartz and chalcopyrite.

Under the ore microscope pyrrhotite occurs as disseminated crystals, commonly parallel to foliation (Fig. 7) or as intergrowths with chalcopyrite (Fig. 8). In some sections chalcopyrite fills the cracks in pyrrhotite crystals. Some pyrrhotite crystals are rimmed by thin marcasite films and penetrated by $\mathrm{FeS}_{2}$ (marcasite?) along the cleavage planes (Fig. 9). 


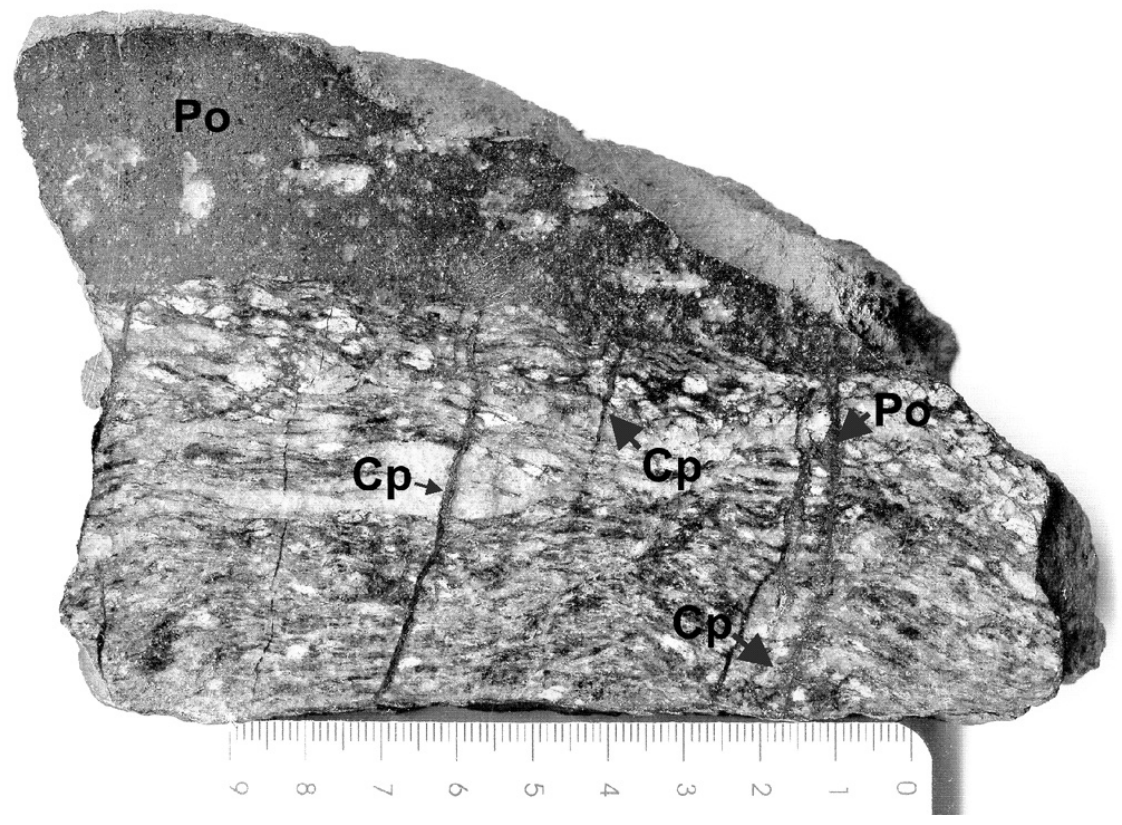

Fig. 6. Massive accumulations and veinlets of pyrrhotite (Po) accompanied by chalcopyrite (Cp). Massive aggregates are concordant with the foliation of hosting hornfels. Sample SD-12

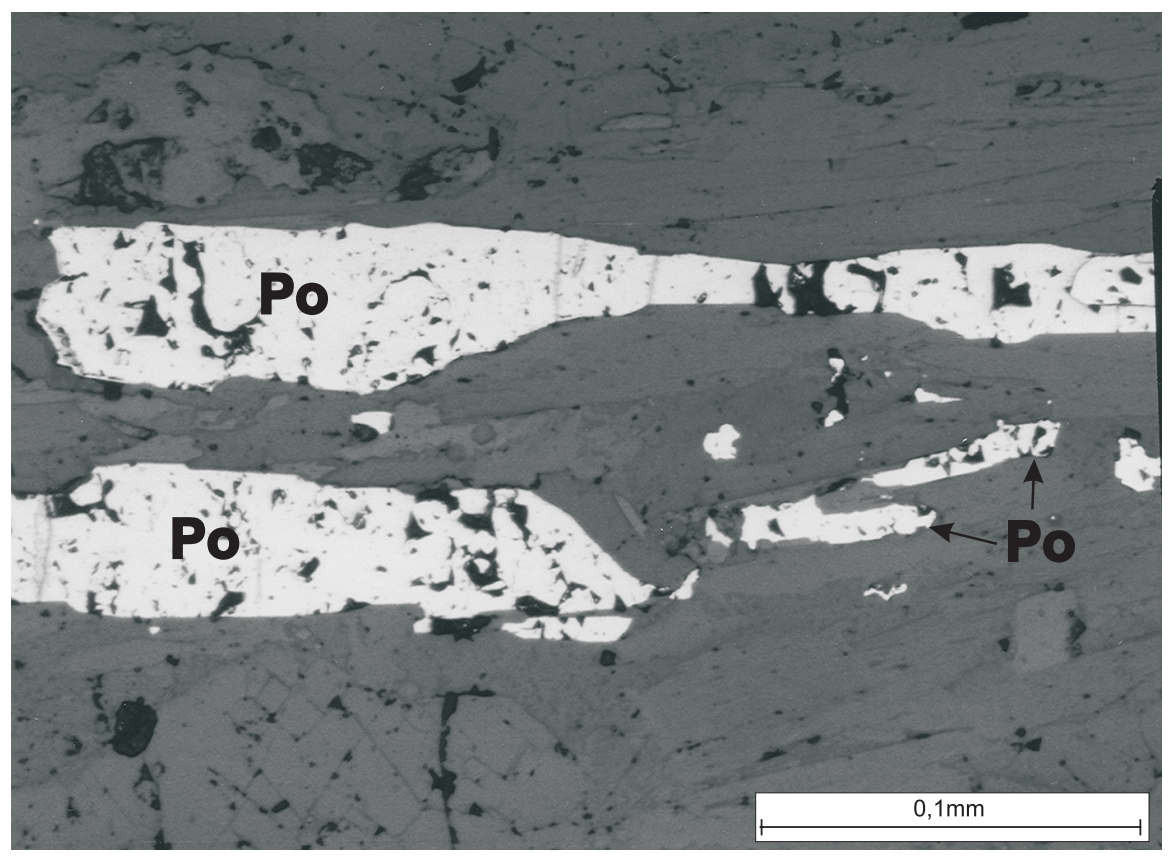

Fig. 7. Disseminated pyrrhotite (Po) crystals arranged parallelly to foliation of hosting hornfelses. Sample G-5. Plane polarized reflected light 


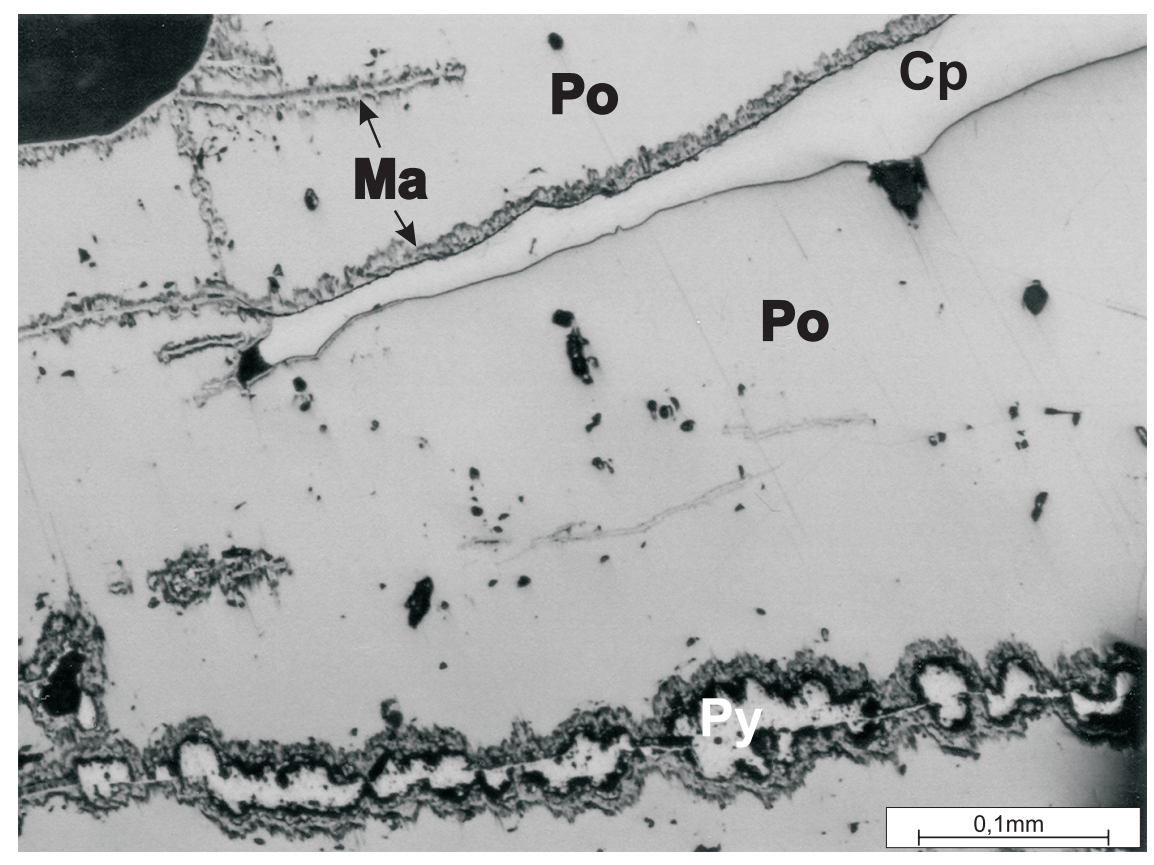

Fig. 8. Intergrowths of pyrrhotite (Po), elongated chalcopyrite (Cp) and pyrite (Py) aggregates. Pyrrhotite is replaced by marcasite rims (Ma). Sample SD-5. Plane polarized reflected light

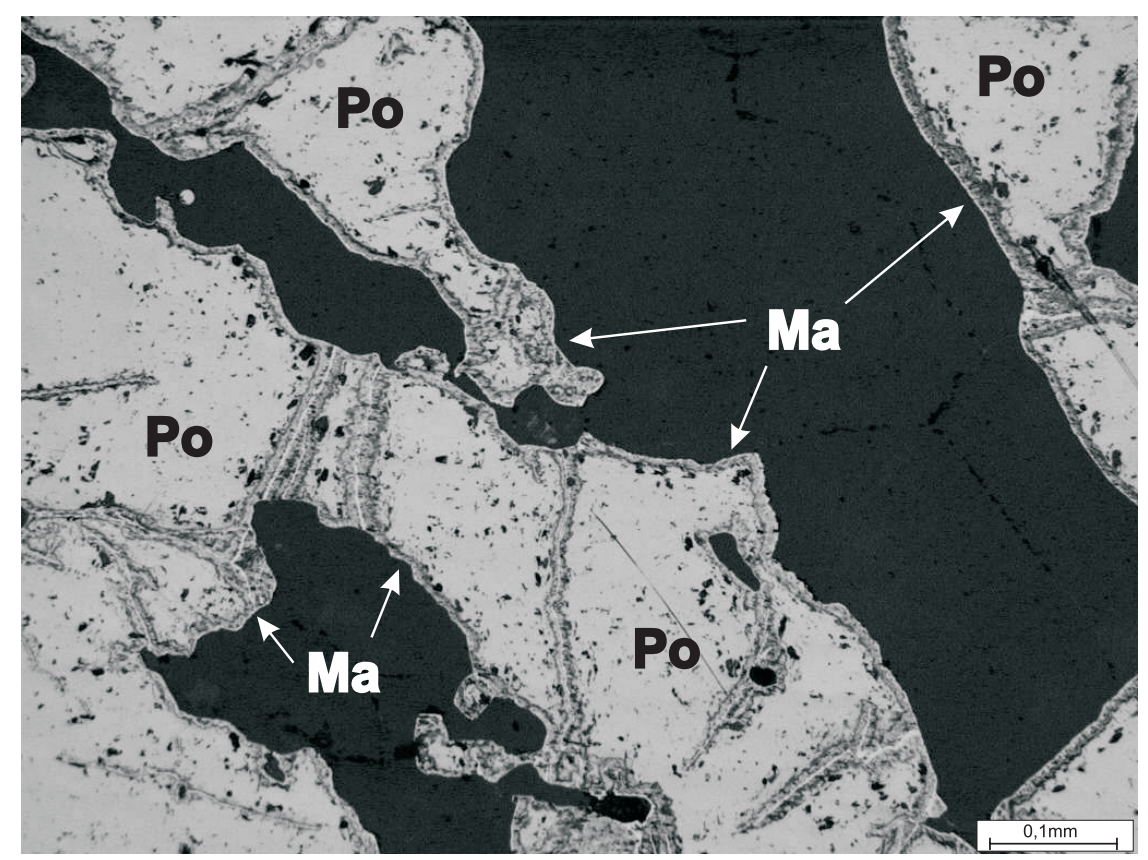

Fig. 9. Xenomorphic pyrrhotite (Po) with intergrowths of gangues (black dots) replaced by marcasite (Ma) along crystal margins and cleavage planes. Sample SD-12. Plane polarized reflected light 
The results of microprobe analyses of pyrrhotite are given in Table 1. Pyrrhotite contains small amounts of Co (0.05-0.06 wt.\%), Ni (0.05-0.18 wt.\%) and As (0.02-0.03 wt.\%). Proportions of Fe and S vary from grain to grain, hence, $\mathrm{N}_{\mathrm{FeS}}$ - the mol fraction of FeS in the FeS-S 2 system (Toulmin, Barton 1964) changes from 0.923(1) to 0.939(3).

TABLE 1

Chemical composition of Ti minerals from Sowia Dolina analysed with an electron microprobe (in wt.\%)

\begin{tabular}{|c|c|c|c|c|}
\hline & \multirow{2}{*}{$\begin{array}{l}\text { Rutile } \\
\mathrm{n}=3\end{array}$} & \multicolumn{3}{|c|}{ Ilmenite } \\
\hline & & $\mathrm{n}=3$ & $\mathrm{n}=7$ & $\mathrm{n}=1$ \\
\hline $\mathrm{FeO}$ & 0.66 & 44.40 & 38.88 & 36.14 \\
\hline $\mathrm{MnO}$ & b.d.l. & 2.66 & 6.64 & 10.38 \\
\hline $\mathrm{TiO}_{2}$ & 98.05 & 51.91 & 52.86 & 52.81 \\
\hline $\mathrm{SnO}_{2}$ & b.d.l. & 0.03 & b.d.l. & b.d.l. \\
\hline $\mathrm{Nb}_{2} \mathrm{O}_{5}$ & 0.13 & 0.07 & b.d.l. & b.d.l. \\
\hline $\mathrm{WO}_{3}$ & 0.04 & b.d.l. & b.d.l. & b.d.l. \\
\hline $\mathrm{Al}_{2} \mathrm{O}_{3}$ & 0.15 & b.d.l. & b.d.l. & b.d.l. \\
\hline $\mathrm{V}_{2} \mathrm{O}_{3}$ & 0.71 & 0.24 & 0.33 & 0.40 \\
\hline Total & 99.75 & 99.31 & 98.71 & 99.73 \\
\hline \multicolumn{5}{|c|}{ Number of cations calculated on the basis of two oxygens (rutile) and three oxygens (ilmenite) } \\
\hline $\mathrm{Fe}$ & 0.007 & 0.945 & 0.826 & 0.762 \\
\hline Mn & $<0.001$ & 0.057 & 0.143 & 0.222 \\
\hline $\mathrm{Ti}$ & 0.988 & 0.994 & 1.010 & 1.002 \\
\hline Sn & $<0.001$ & $<0.001$ & $<0.001$ & $<0.001$ \\
\hline $\mathrm{Nb}$ & 0.001 & 0.001 & $<0.001$ & $<0.001$ \\
\hline W & $<0.001$ & $<0.001$ & $<0.001$ & $<0.001$ \\
\hline $\mathrm{Al}$ & 0.002 & $<0.001$ & $<0.001$ & $<0.001$ \\
\hline V & 0.008 & 0.005 & 0.007 & 0.008 \\
\hline
\end{tabular}

$\mathrm{n}$ - number of analytical points.

b.d.1. - below detection limit.

Chalcopyrite forms two varieties. Chalcopyrite I reveals intergrowths with pyrrhotite (Fig. 8) and pyrite or occurs as independent crystals in quartz-feldspar veinlets. Chalcopyrite II forms exsolutions in sphalerite crystals either arranged as minute inclusions along the cleavage planes or randomly scattered as larger crystals (Fig. 10). 


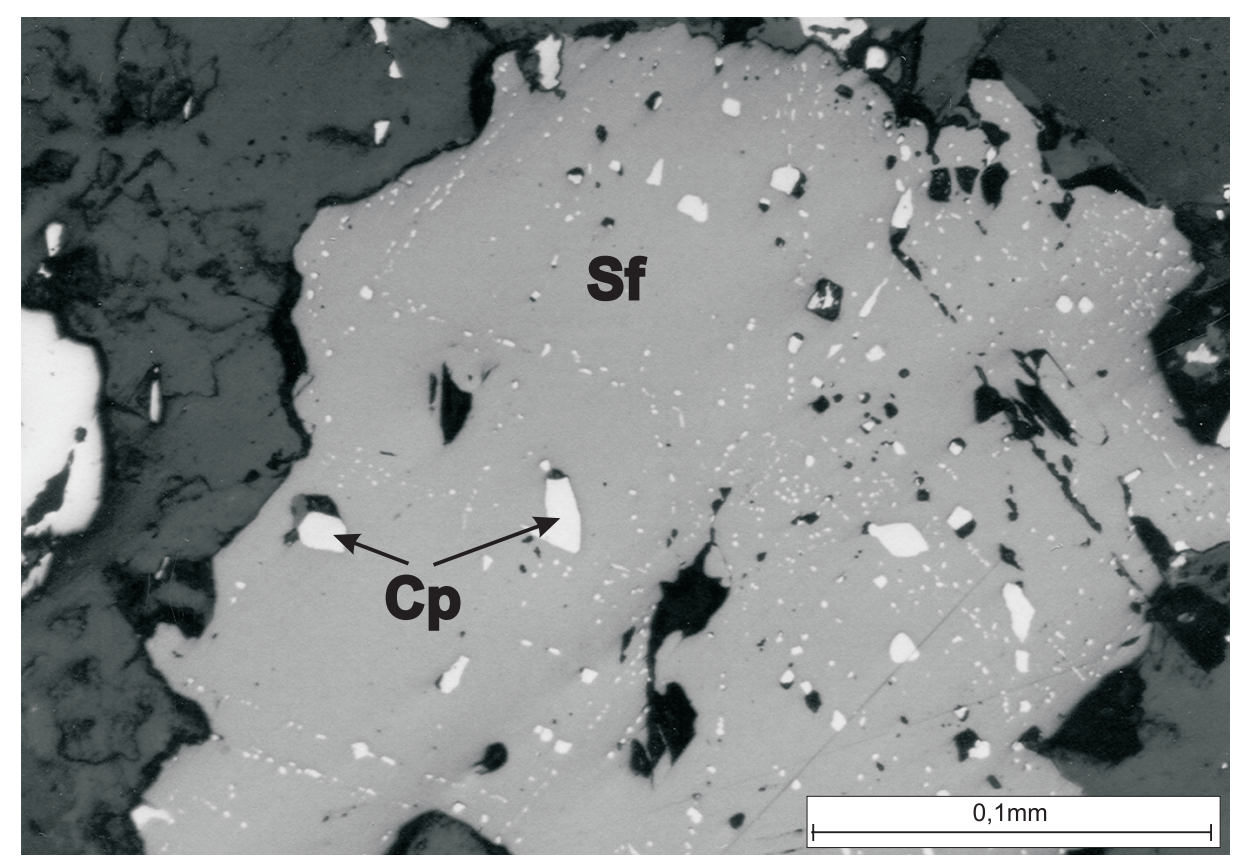

Fig. 10. Chalcopyrite (Cp) exsolutions in sphalerite (Sf) arranged randomly (large crystals) or along cleavage planes (fine crystals). Sample SD II-15. Plane polarized reflected light

Microprobe chemical composition of chalcopyrite is given in Table 1. High contents of $\mathrm{Zn}$ (up to $2.16 \mathrm{wt}$.\%) are typical of exsolutions in sphalerite. Such a content may result from limited $\mathrm{CuFeS}_{2}-\mathrm{ZnS}$ solid solution or may be an effect of crypto-inclusions of sphalerite (Scott 1983). Moreover, Ag contents up to $0.07 \mathrm{wt} . \%$ were detected.

Sphalerite usually forms accumulations in quartz-feldspar veinlets. It occurs as single crystals (Fig. 10) or as irregular intergrowths with pyrite. Most of sphalerite grains contain exsolutions of chalcopyrite. Intergrowths with galena were noticed as well.

Results of microprobe chemical analyses (Table 1) indicate the presence of Fe-sphalerite with $\mathrm{Fe}$ contents from 5.8 to $8.5 \mathrm{wt} . \%$ (mean value $7.81 \mathrm{wt}$.\%). Mean molal FeS content is $13.6 \pm 2.0 \mathrm{~mol} \%$. Some amounts of $\mathrm{Cd}$ were detected (mean value $0.45 \mathrm{wt} . \%$ )

Pyrite accumulates in veins (sample SD-4) and as small crystals randomly disseminated in the host rocks. Hipidiomorphic pyrite crystals forming intergrowths with arsenopyrite as well as with chalcopyrite were also found.

In sample L2 skeleton structures of pyrite were encountered (Fig. 11) in association with arsenopyrite and marcasite. Such pyrite structures were interpreted by Ramdohr (1969) as the result of "pyrrhotite resorption".

Arsenopyrite was found in quartz veins, in association with pyrite (Fig. 12), chalcopyrite, sphalerite (Fig. 13) and galena but its individual aggregates were also observed.

Arsenopyrite crystals are free of $\mathrm{Co}$ and $\mathrm{Ni}$ admixtures (Table 1). Characteristic are variable S-As substitutions (Table 1). As contents fall into the range of $30.3 \pm 1.1(2 \sigma)$ at. $\%$. 


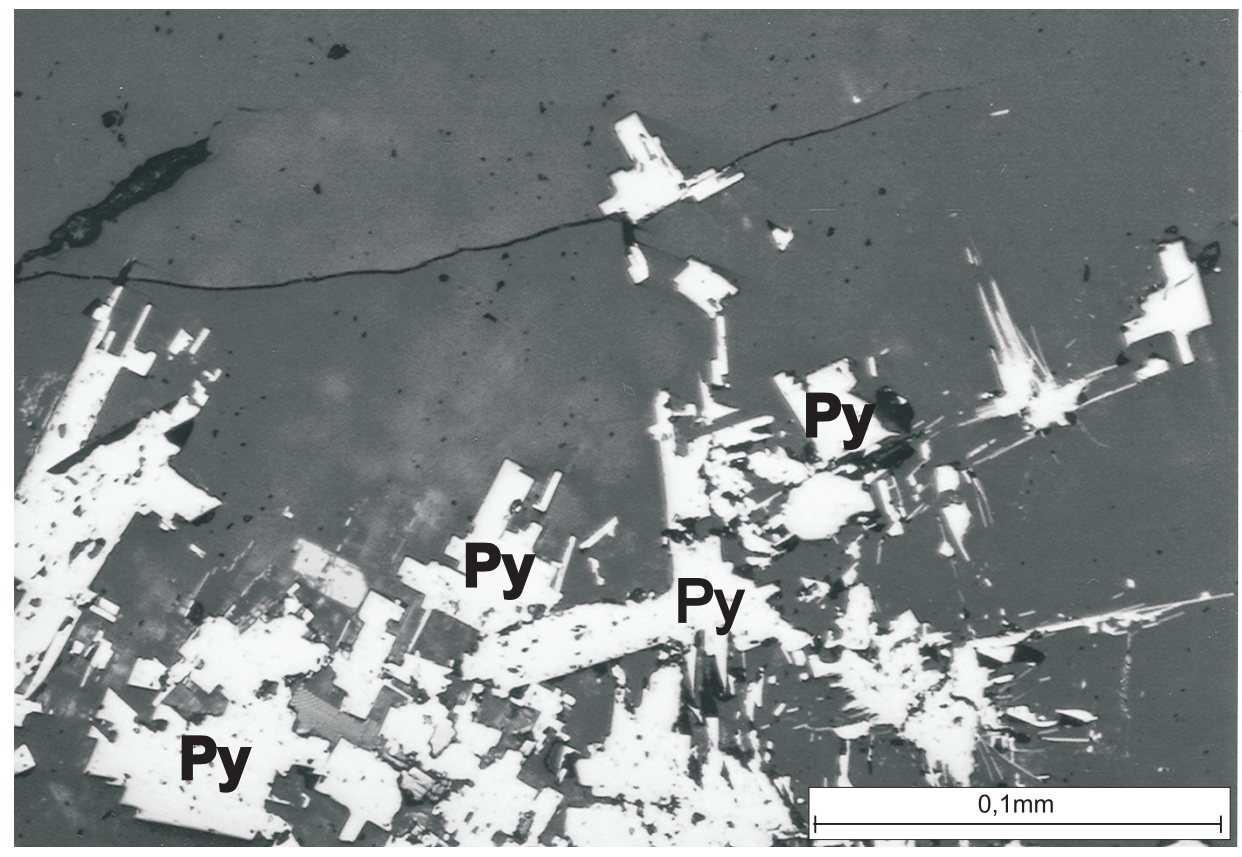

Fig. 11. Hypidiomorphic and needle-like pyrite (Py) crystals forming "skeleton" structures. Sample L2. Plane polarized reflected light

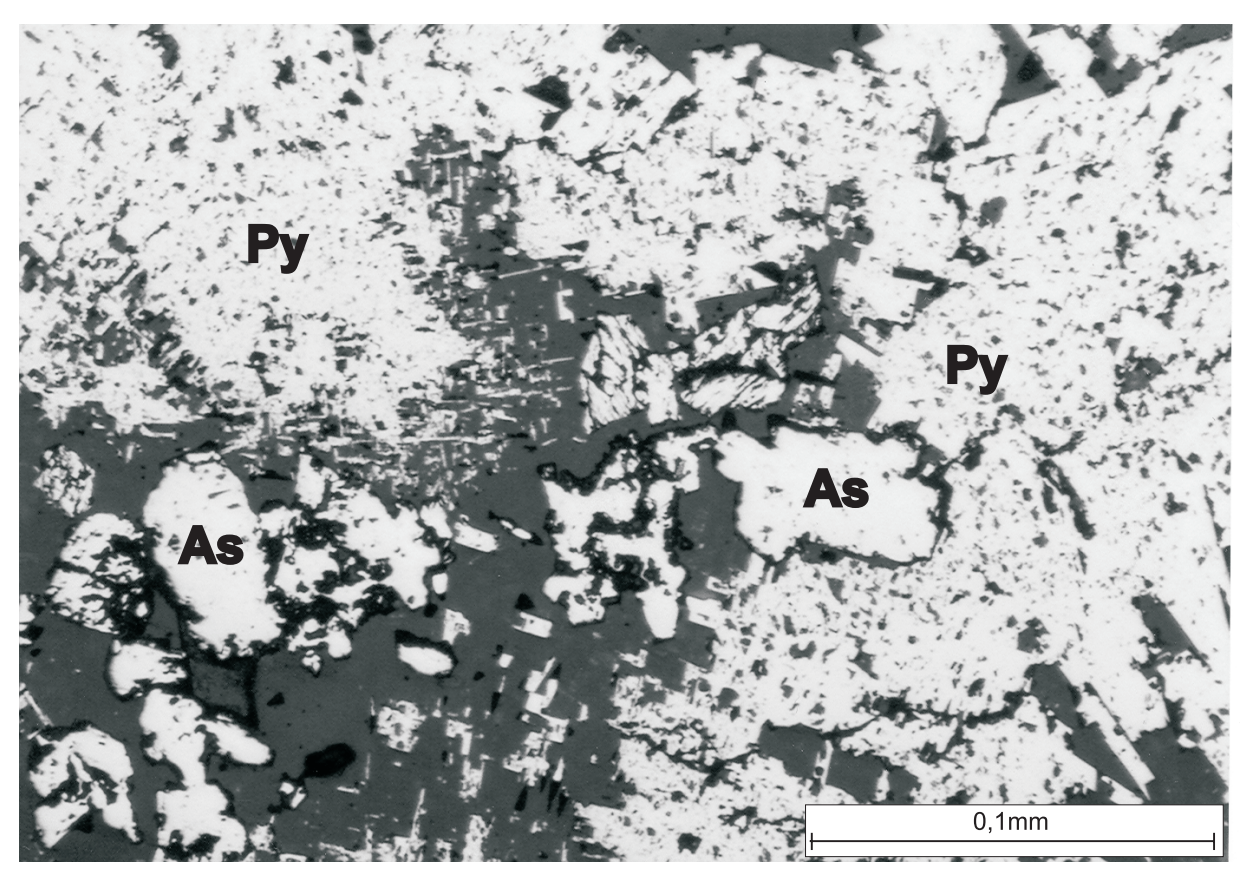

Fig. 12. "Skeleton" pyrite (Py) intergrown with arsenopyrite (As). Sample L2. Plane polarized reflected light 


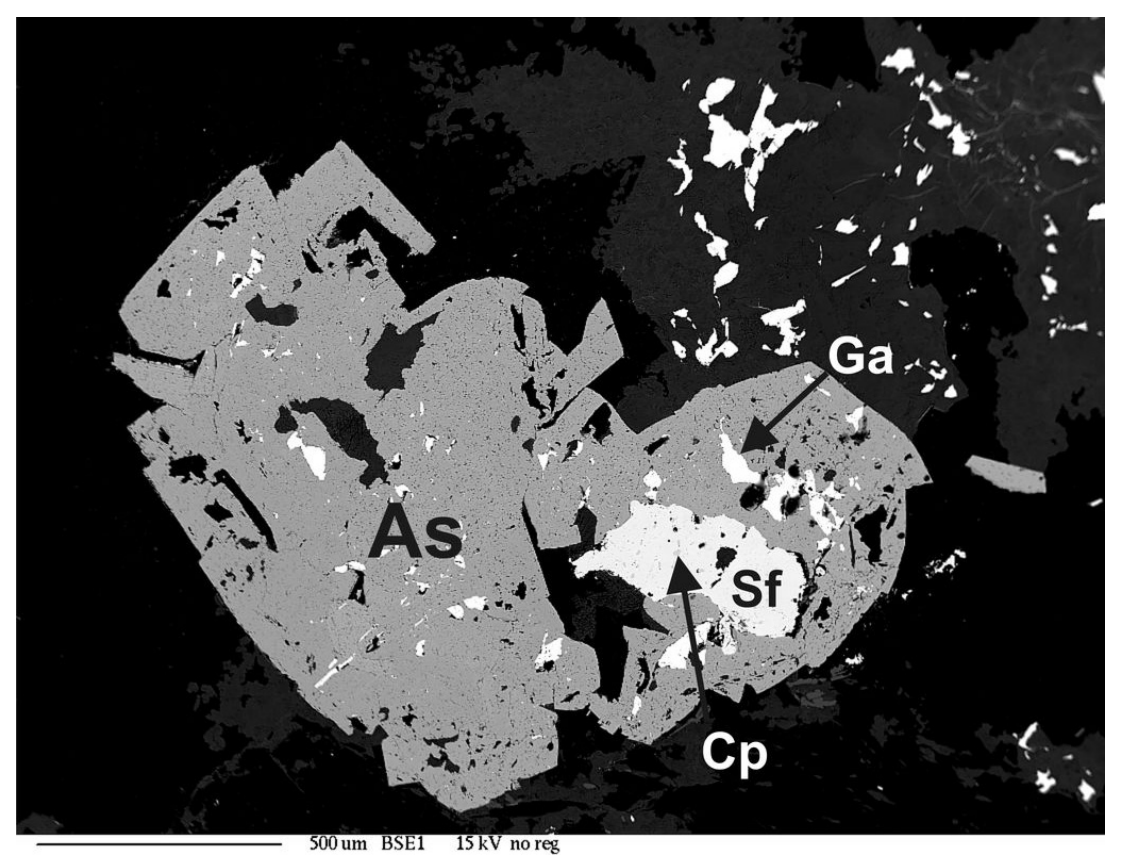

Fig. 13. Hipidiomorphic arsenopyrite aggregate intergrown with sphalerite (Sf), chalcopyrite (Cp) and galena (Ga). Sample SD-15, BSE image.

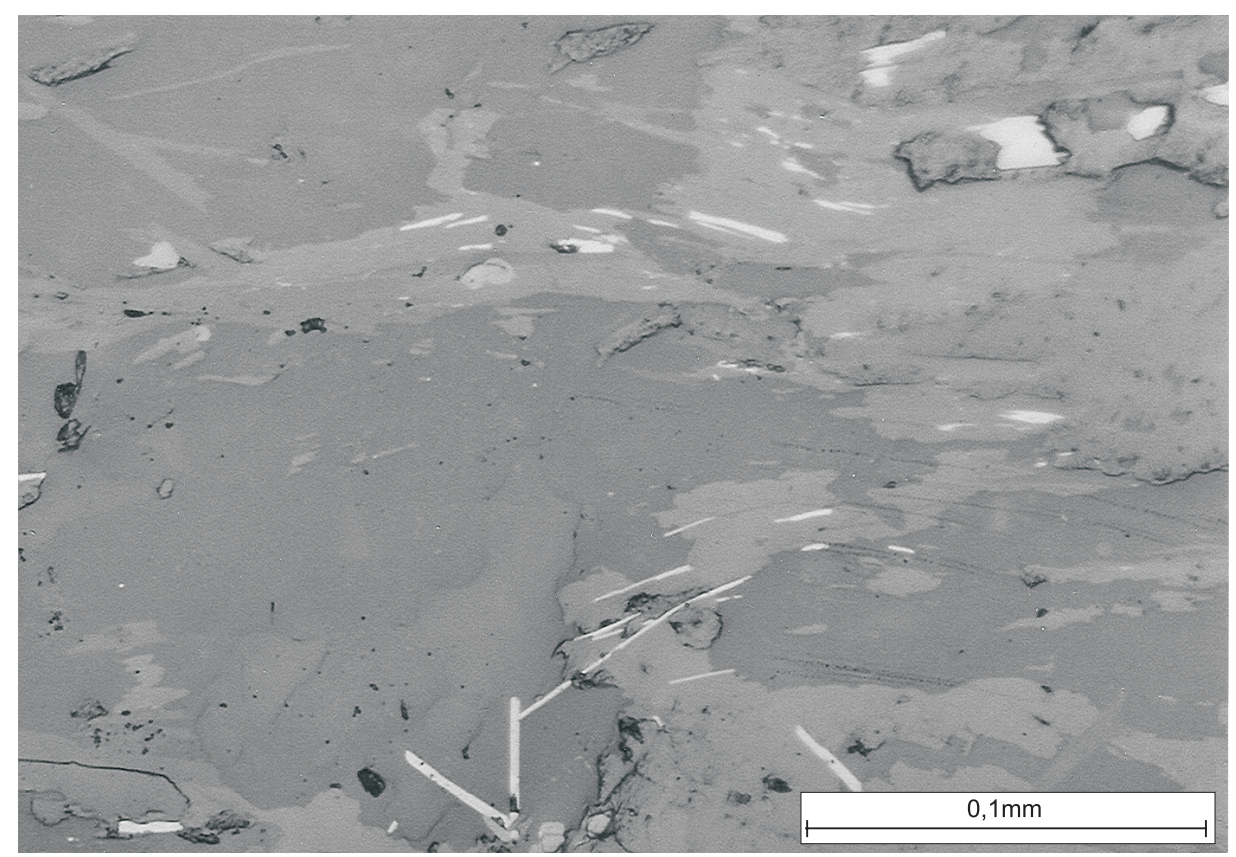

Fig. 14. Lamellar Ti minerals (light grey) arranged parallelly to hornfels foliation. Sample SD-15. Plane polarized reflected light 


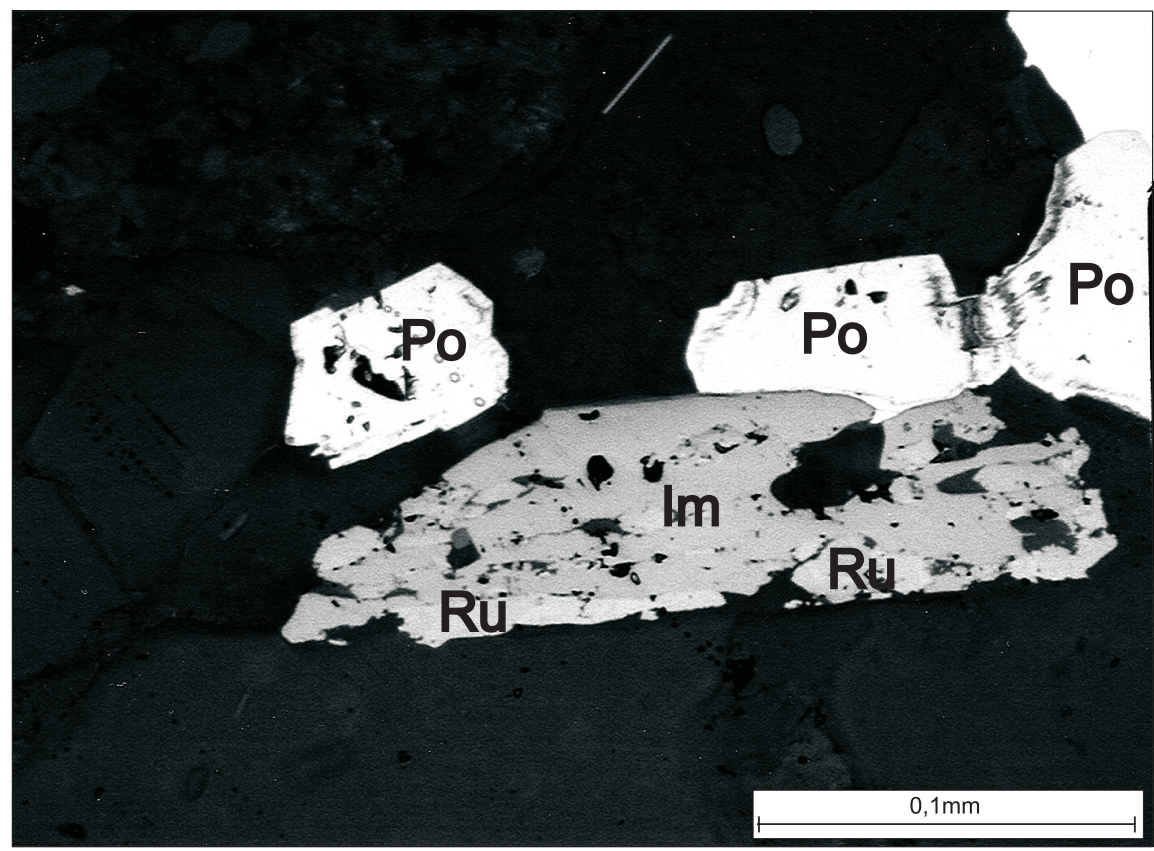

Fig. 15. Ilmenite (Im) and rutile (Ru) intergrowth accompanied by pyrrhotite (Po). Sample SD-15. Plane polarized reflected light

Galena occurs as small intergrowths in sphalerite and arsenopyrite (Fig. 13). Chemical composition indicates its two varieties: Ag-rich (mean value $0.76 \mathrm{wt.} \%$ ) and Ag-poor (mean value 0.11 wt.\%). No Ag minerals have been observed, thus, small amounts of silver are substituted in the PbS lattice.

Ti minerals (ilmenite and rutile) were found as single, disseminated crystals usually arranged parallel to foliation (Fig. 14) and as mutual intergrowths, in which ilmenite is replaced by rutile (Fig. 15). Chemical composition of ilmenite and rutile is presented in Table 2.

Bornite was found only in a single sample as intergrowths with chalcopyrite.

Marcasite forms thin coatings on pyrrhotite crystals and/or penetrates into $\mathrm{FeS}$ aggregates (Fig. 9).

\section{FLUID INCLUSION STUDIES}

The preliminary results of fluid inclusion examinations in quartz veins from the Sowia Dolina are summarized below:

- type I includes large, V + L inclusions (up to $70 \mathrm{~nm}$ ), mostly regular in shape. Gas phase $\left(\mathrm{CO}_{2}\right)$ constitutes up to $80 \%$ of bubble volume,

- type II is represented by smaller, irregular inclusions with $\mathrm{CO}_{2}$ filling less than $40 \%$ of bubble volume,

- type III includes small, irregular inclusions with low gas volume. 
TABLE 2

Chemical composition of sulphides from Sowia Dolina analysed with the an electron microbe (in wt.\%)

\begin{tabular}{|c|c|c|c|c|c|c|c|c|c|}
\hline & \multicolumn{2}{|c|}{ Pyrrhotite } & \multirow{2}{*}{$\begin{array}{l}\text { Pyrite } \\
\mathrm{n}=13\end{array}$} & \multirow{2}{*}{$\begin{array}{l}\text { Arseno- } \\
\text {-pyrite } \\
\mathrm{n}=13\end{array}$} & \multicolumn{2}{|c|}{ Chalcopyrite } & \multirow{2}{*}{$\begin{array}{l}\text { Spha- } \\
\text {-lerite } \\
\mathrm{n}=28\end{array}$} & \multicolumn{2}{|c|}{ Galena } \\
\hline & $\mathrm{n}=5$ & $\mathrm{n}=15$ & & & $\mathrm{n}=9$ & $\mathrm{n}=10$ & & $\mathrm{n}=7$ & $\mathrm{n}=4$ \\
\hline$S$ & 39.88 & 39.04 & 52.13 & 21.83 & 34.70 & 34.88 & 33.47 & 13.29 & 13.33 \\
\hline $\mathrm{Mn}$ & b.d.l. & b.d.l. & b.d.l. & b.d.l. & b.d.l. & b.d.l. & 0.06 & - & - \\
\hline $\mathrm{Fe}$ & 59.50 & 60.22 & 46.93 & 35.81 & 30.27 & 30.09 & 7.77 & b.d.l. & b.d.l. \\
\hline $\mathrm{Cu}$ & b.d.l. & b.d.l. & b.d.l. & b.d.l. & 33.57 & 32.08 & 0.10 & b.d.l. & b.d.l. \\
\hline $\mathrm{Zn}$ & - & - & - & - & 0.09 & 2.16 & 57.78 & - & - \\
\hline As & b.d.l. & b.d.l. & b.d.l. & 43.18 & b.d.l. & b.d.l. & - & - & - \\
\hline Se & b.d.l. & b.d.l. & b.d.l. & b.d.l. & b.d.l. & b.d.l. & b.d.l. & 0.06 & b.d.1. \\
\hline $\mathrm{Ag}$ & b.d.l. & b.d.l. & b.d.l. & b.d.l. & b.d.l. & 0.08 & - & 0.76 & 0.11 \\
\hline $\mathrm{Cd}$ & - & - & - & - & b.d.l. & b.d.l. & 0.46 & b.d.l. & b.d.l. \\
\hline In & - & - & - & - & b.d.l. & b.d.l. & 0.02 & b.d.l. & b.d.l. \\
\hline $\mathrm{Pb}$ & - & - & - & - & - & - & - & 85.18 & 86.31 \\
\hline $\mathrm{Bi}$ & - & - & - & b.d.l. & b.d.l. & b.d.l. & - & 0.19 & b.d.l. \\
\hline Co & 0.05 & 0.06 & b.d.l. & b.d.1. & b.d.l. & b.d.l. & - & - & - \\
\hline $\mathrm{Ni}$ & 0.18 & 0.05 & b.d.l. & b.d.l. & b.d.l. & b.d.l. & - & - & - \\
\hline \multirow[t]{2}{*}{ Total } & 99.62 & 99.38 & 99.06 & 100.82 & 98.63 & 99.30 & 99.66 & 99.48 & 99.74 \\
\hline & \multicolumn{9}{|c|}{$\begin{array}{l}\text { Number of ions calculated on the basis of: } \\
\text { pyrrhotite }-\mathrm{S}=1 \mathrm{pfu} \text {; pyrite, sphalerite, galena }-\Sigma_{\text {cations }}=1 \mathrm{pfu} \text {; } \\
\text { chalcopyrite }-\Sigma_{\text {cations }}=2 \mathrm{pfu} \text {; arsenopyrite }-\Sigma_{\text {ions }}=3 \mathrm{pfu}\end{array}$} \\
\hline$S$ & 1.000 & 1.000 & 1.935 & 1.076 & 2.020 & 2.019 & 1.014 & 0.989 & 0.995 \\
\hline $\mathrm{Mn}$ & & & & & & & 0.001 & & \\
\hline $\mathrm{Fe}$ & 0.857 & 0.886 & 1.000 & 1.013 & 1.012 & 1.000 & 0.135 & & \\
\hline $\mathrm{Cu}$ & & & & & 0.986 & 0.937 & 0.002 & & \\
\hline $\mathrm{Zn}$ & & & & & 0.002 & 0.061 & 0.858 & & \\
\hline As & & & & 0.911 & & & & & \\
\hline Se & & & & & & & & 0.002 & \\
\hline $\mathrm{Ag}$ & & & & & & 0.001 & & 0.017 & 0.002 \\
\hline $\mathrm{Cd}$ & & & & & & & 0.004 & & \\
\hline In & & & & & & & 0.000 & & \\
\hline $\mathrm{Pb}$ & & & & & & & & 0.981 & 0.998 \\
\hline $\mathrm{Bi}$ & & & & & & & & 0.003 & \\
\hline Co & 0.001 & 0.001 & & & & & & & \\
\hline $\mathrm{Ni}$ & 0.002 & 0.001 & & & & & & & \\
\hline
\end{tabular}

$\mathrm{n}$ - number of analytical points.

b.d.1. - below detection limit. 
In the type I inclusions, $\mathrm{CO}_{2}$ melting occurred at $-60 \pm 0.1^{\circ} \mathrm{C}$. The beginning of ice melting took place between -22.3 and $-15^{\circ} \mathrm{C}$ and melting was completed between -8.2 and $-1.9^{\circ} \mathrm{C}$. Melting of gas hydrate occurred between -7.4 and $-126^{\circ} \mathrm{C}$, only in a single sample the temperature $2.9^{\circ} \mathrm{C}$ was measured. Carbon dioxide homogenization towards the gas phase has started at $7-17^{\circ} \mathrm{C}$, whereas complete homogenization took place at $330-380^{\circ} \mathrm{C}$. Some inclusions were subjected to decrepitation at about $340^{\circ} \mathrm{C}$.

In the type II inclusions, complete $\mathrm{CO}_{2}$ melting was observed at -56.7 to $-54.4^{\circ} \mathrm{C}$. Ice melting took place at about $-2^{\circ} \mathrm{C}$ and total homogenization occurred between 205 and $288^{\circ} \mathrm{C}$.

In the type III inclusions, only ice melting was observed at -2 to $0^{\circ} \mathrm{C}$ and total homogenization proceeded between 150 and $165^{\circ} \mathrm{C}$.

\section{ORE MINERALS SUCCESSION AND FORMATION TEMPERATURES}

Basing upon microscopic studies of polished sections, analysis of host rock structures and ore minerals intergrowths, the succession of ore minerals was proposed (Fig. 16).

The oldest ore minerals are ilmenite and rutile. Both phases form disseminated structures concordant with foliation (Fig. 14). Time relations between them are unclear but, occasionally, replacements of ilmenite by rutile were observed (Fig. 15). Origin of Ti minerals can be linked to regional metamorphism during which mica schists were formed.

Early pyrrhotite was formed after Ti minerals, as suggested by aggregates shown in Figure 15. Chalcopyrite is generally younger than pyrrhotite (Fig. 8). Its older generation forms intergrowths with pyrrhotite but the younger one occurs as exsolutions in sphalerite being simultaneous with it (Fig. 10). Sphalerite, arsenopyrite and galena probably crystallized simultaneously as the last primary sulphides.

The position of pyrite is unclear. "Skeletal" pyrite was interpreted by Ramdohr (1969) as a product of "pyrrhotite resorption", hence, pyrite should follow pyrrhotite in succession.

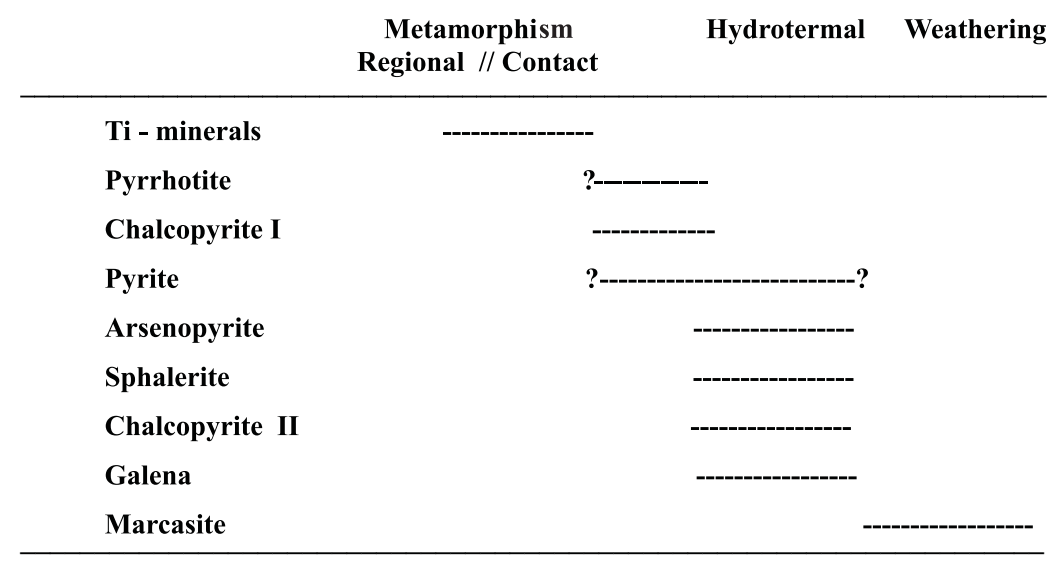

Fig. 16. Ore mineral succession in the Sowia Dolina mineralization site 


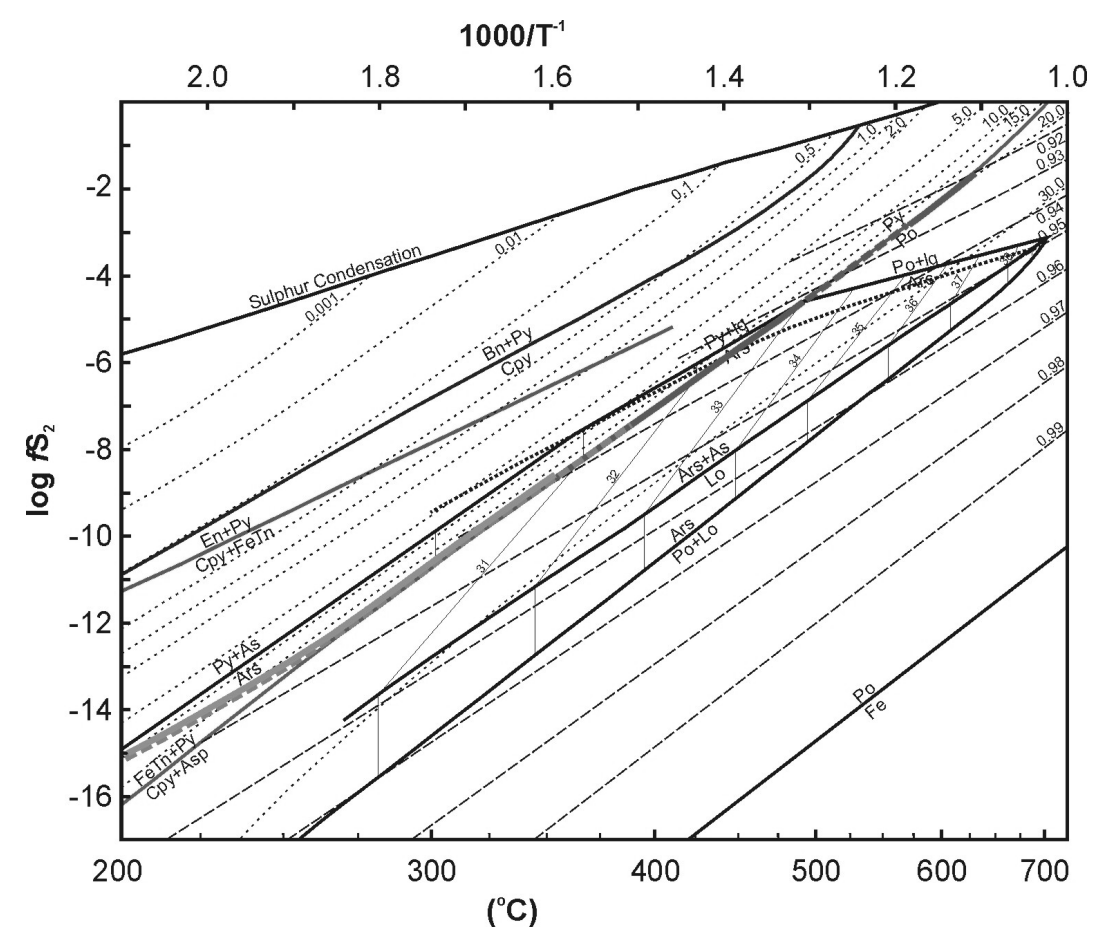

Fig. 17. Thermochemical conditions of ore assemblage crystallization from the Sowia Dolina site

The succession of primary sulphides (Fig. 16) was confirmed by formation temperatures of some ore minerals concluded from the results of microprobe analyses. As shown above, formation temperatures of pyrrhotite fall into the range $630-265^{\circ} \mathrm{C}$ and those of arsenopyrite were close to $390^{\circ} \mathrm{C}$ (Fig. 17).

Marcasite is a secondary mineral, formed at the initial stages of sulphide weathering. Its origin will be discussed in a separate paper.

Comparison of microscopic observations and chemical data with petrologic studies of hornfelses allows to conclude that the beginning of contact metamorphism determined by transformation of muscovite into sillimanite at above $600^{\circ} \mathrm{C}$ corresponds to the formation of high-temperature pyrrhotite. Other sulphides (arsenopyrite) formed at temperatures below $390^{\circ} \mathrm{C}$, which corresponds to a lower-temperature, hydrothermal stage.

The lower boundary of ore formation temperatures is determined by formation of vein quartz, which took place between 380 and $150^{\circ} \mathrm{C}$, as revealed by preliminary FI studies.

\section{DISCUSSION}

In the Karkonosze-Izera Massif several ore deposits and occurrences of ore minerals are known (e.g., Petrascheck 1933; Mochnacka, Pošmourny 1981; Mochnacka 2000 and others). Recently, none of them is of economic value, however, they contribute to the 
know- ledge of processes that operated in the neighbourhood of the Karkonosze granite intrusion.

Generally, the deposits and occurrences are situated mostly in the metamorphic envelope of the Karkonosze granite. Several types are represented: (i) magnetite deposits and occurrences (Kowary, Szklarska Poręba, Miedzianka), (ii) a pyrite deposit (Wieściszowice), (iii) an arsenopyrite deposit (Czarnów), (iv) tin deposits (Gierczyn-Przecznica), (v) a polymetallic, Cu-dominated deposit (Miedzianka), (vi) a polymetallic, U-dominated deposit (Kowary), (vii) U deposits (Radoniów, Podgórze), and (viii) some other occurrences of purely scientific importance around the granite (e.g., Rędziny, see Mochnacka 2000; Pieczka et al. 2005). Ore mineralization is a separate problem within the Karkonosze granite intrusion (e.g., Kozłowski et al. 2002).

Some of these deposits and occurrences are of pre-Variscan age (e.g., the Kowary magnetite deposit, the Wieściszowice pyrite deposit) and the age of others (e.g., the Gierczyn tin deposit) is still a matter of discussion (see Mochnacka et al. 1999; Michniewicz et al. 2006).

Most of the ore deposits and occurrences mentioned above are of hydrothermal origin and reveal a strong genetic link to the Karkonosze granite (Mochnacka 2000). The ore mineralization in Sowia Dolina belongs to this group as well. The hydrothermal system developed around the granite intrusion was the possible main source of elements and hydrothermal fluids circulating presumably along transverse faults as well as the source of driving thermal energy.

In Sowia Dolina pyrrhotite is the dominant ore mineral. Its formation took place at the temperature range from 630 to $265^{\circ} \mathrm{C}$. Similar assemblage of ore minerals was found in the Budniki exploration site located some $4 \mathrm{~km}$ east of Sowia Dolina, where pyrrhotite is also the oldest sulphide in the paragenesis and its formation temperatures fall into the range $580-440^{\circ} \mathrm{C}$ (see Mochnacka et al., in press). Moreover, some similarities to the Gierczyn-Przecznica (Wiszniewska 1984) and the Czarnów deposits can be found, where pyrrhotite accumulations formed at a high-temperature stage, whereas the accompanying ore minerals crystallized at lower temperatures. All the sites discussed are situated in vicinity of the Karkonosze granite and represent the products of hydrothermal ore deposition in the contact aureole of the granite.

\section{CONCLUSIONS}

Basing on the results of studies presented here, the following conclusions have been drawn:

1. The Sowia Dolina occurrence of sulphides is an example of hydrothermal mineralization genetically related to the Karkonosze granite in which a high-temperature mineral (pyrrhotite, $630-265^{\circ} \mathrm{C}$ ) dominates.

2. The highest temperatures of pyrrhotite formation are similar to the formation temperatures of hornfelses from the contact metamorphism zone. The character of pyrrhotite and gangue intergrowths suggests the high-temperature replacement phenomena. 
3. The mineralization process continued at lower temperatures, when low-temperature pyrrhotite and minor accompanying sulphides (sphalerite, galena, chalcopyrite) crystallized. Final episode contained crystallization of vein quartz at the temperature $150^{\circ} \mathrm{C}$.

4. The Sowia Dolina site represents the highest-temperature member of mineral succession among all the deposits and sites related to the metamorphic envelope of the Karkonosze granite.

Acknowledgements. Sincere thanks are due to Dr. Piotr Dzierżanowski and Ms. Lidia Jeżak from the Warsaw University for their kind assistance in carrying out the microprobe analyses. The research project was financed by the Polish Committee for Scientific Research, grant No. 5 T12B 03625.

\section{REFERENCES}

BARTON B. P., TOULMIN P., 1966: Phase relationships involving sphalerite in the Fe-Zn-S system. Economic Geology 61, 815-848.

BERG G., 1923: Die Gesteine des Isergebirges. Jahrbuch des Preussischen Geologische Landesanstalt 43, $125-168$.

BORKOWSKA M., HAMEURT J., VIDAL P., 1980: Origin and age of Izera gneisses and Rumburk granites in the Western Sudetes. Acta Geologica Polonica 30, 121-146.

CHALOUPSKÝ J., 1965: Metamorphic development of the Krkonoše crystalline complex. Krystalinikum 3 , $31-54$.

CHALOUPSKÝ J., (ed.) 1989: Geology of the Krkonoše and Jizerské hory Mts (in Czech with English summary). Ústředni ústav geolologický, Praha, $288 \mathrm{pp}$

DUTHOU J.L., COUTURIE J.P., MIERZEJEWSKI M.P., PIN C., 1991: Next dating of granite sample from the Karkonosze Mountains using Rb-Sr total rock isochrone method (in Polish with English abstract). Przegląd Geologiczny 36, 75-79.

HOEHNE K., 1952: Vorkommen von Magnetit in Schlesien. Neues Jahrbuch für Geologie und Paläontologie Monatshefte 7, 289-294.

KERESTEDJIAN T., 1997: Chemical and morphological features of arsenopyrite, concerning its use as geothermometer. Contributions to Mineralogy and Petrology 60, 231-234.

KORYTOWSKI A., DÖRR W., ŻELAŹNIEWICZ A., 1993: U-Pb dating of (meta) granitoids in the NW Sudetes (Poland) and their bearing on tectono-stratigraphic correlation. Terra Abstracts 5, 331-332.

KOZŁOWSKI A., SANOCKA M., DZIERŻANOWSKI P., 2002: Tin-tungsten and associate mineralisation at Szklarska Poręba Huta, Karkonosze Massif, SW Poland. Polskie Towarzystwo Mineralogiczne - Prace Specjalne (Mineralogical Society of Poland - Special Papers) 20, 248-250.

KRETSCHMAR K., SCOTT J., 1976: Phase relations involving arsenopyrite in the system Fe-As-S. Canadian Mineralogist 14, 364-386.

KRÖNER A., HEGNER E., HAMMER J., HAASE G., BIELICKI K-H., KRAUSS M., EIDAM J., 1994: Geochronology and Nd-Sm systematics of Lusatian granitoids: significance for the evolution of the Variscan orogen in east-central Europe. Geologische Rundschau 83, 357-376.

KRÖNER A., JAECKEL P., HEGNER E., OPLETAL M., 2001: Single zircon ages and whole-rock Nd isotopic systematics of early Palaeozoic granitoid gneisses from the Czech and Polish Sudetes (Jizerské hory, Krkonoše Mountains and Orlice-Snežník Complex). International Journal of Earth Sciences (Geologische Rundschau) 90, 304-324.

KRYZA R., MAZUR S., 1995: Contrasting metamorphic paths in the SE part of the Karkonosze-Izera Block (Western Sudetes, SW Poland). Neues Jahrbuch für Mineralogie. Abhandlungen 169, 157-192.

MACHOWIAK K., ARMSTRONG R., 2007: SHRIMP U-Pb zircon age from the Karkonosze granite. Polskie Towarzystwo Mineralogiczne - Prace Specjalne (Mineralogia Polonica - Special Papers) 31, 193-196. 
MAZUR S., 1995: Structural and metamorphic evolution of the country rocks at the eastern contact of the Karkonosze granite in the southern Rudawy Janowickie Mts and Lasocki Range. Geologia Sudetica 29, 31-98 (in Polish with English abstract).

MAZUR S., ALEKSANDROWSKI P., 2001: The Tepla(?)/Saxothuringian suture in the Karkonosze-Izera Massif, Western Sudetes, Central European Variscides. International Journal of Earth Sciences 90, 341-360.

MICHNIEWICZ M., BOBIŃSKI W., SIEMIĄTKOWSKI J., 2006: Tin mineralization in the middle part of the Stara Kamienica Belt (western Sudetes). Prace Państwego Instytutu Geologicznego CLXXXV, pp. 136 (in Polish with English abstract).

MOCHNACKA K., 2000: Prawidłowości wykształcenia mineralizacji kruszcowej w metamorficznej osłonie granitu Karkonoszy - próba powiązania ze środowiskiem geotektonicznym. (Regularities in the development of ore mineralization in the metamorphic cover of the Karkonosze granite - an attempt to identify geotectonic situation). Polskie Towarzystwo Mineralogiczne - Prace Specjalne (Mineralogical Society of Poland - Special Papers) 16, 223-258 (in Polish).

MOCHNACKA K., POŠMOURNY K., 1981: Metallogenetic characteristics of the Palaeozoic and pre-Palaeozoic formations of the northern part of the Bohemian Massif (Krkonošse - Jizerské hory region). Časopis pro mineralogii a geologii 26,1, 29-43.

MOCHNACKA K., MAYER W., PIESTRZYŃSKI A., KUCHA W., 1999: Petrology of cassiterite aggregates from Gierczyn area, SW Poland. In: Stanley C. J. et al. (eds) - Mineral Deposits: Processes to Processing, $397-400$.

MOCHNACKA K., OBERC-DZIEDZIC T., MAYER W., PIECZKA A., (in press): Ti remobilization and superimposed, low-grade $\mathrm{Fe}-\mathrm{Cu}-\mathrm{Ni}$-Co-sulphide/sulphoarsenide mineralization in amphibolites - an example of thermal and chemical activity of granite intrusion (the Karkonosze-Izera Massif, SW Poland). Geological Quarterly .

MUSZER A., 2005: Kopaliny użyteczne regionu karkonoskiego. (Mineral raw materials in the Karkonosze region). In: Mierzejewski M. P. (ed.) - Karkonosze - przyroda nieożywiona i człowiek, Wydawnictwo Uniwersytetu Wrocławskiego, 271-292 (in Polish).

OBERC-DZIEDZIC T., 2003: The Izera granites: an attempt of the reconstruction of pre-deformational history. In: Ciężkowski W., Wojewoda J., Żelaźniewicz A. (eds) - Sudety Zachodnie: od wendu do czwartorzędu, 41 - 52, WIND, Wrocław (in Polish with English abstract).

OLIVER G. J. H., CORFU F., KROUGH T. E., 1993: U-Pb ages from SW Poland: evidence for a Caledonian suture zone between Baltica and Gondwana. Journal of Geological Society, London 150, 355-369.

PETRASCHECK E.W., 1933: Die Erzlagerstätten des Schlesischen Gebirges. Archiv für Lagerstättenforschung 59, 5-53.

PIECZKA A., GOŁĘBIOWSKA B., PARAFINIUK J., 2005: Formation conditions of sulphide mineralization in the Rędziny area (West Sudetes, Poland). Polskie Towarzystwo Mineralogiczne - Prace Specjalne (Mineralogial Society of Poland - Special Papers) 25, 167-171.

PIESTRZYŃSKI A., 2005: Rudy miedzi i srebra. (Copper and silver ores). In: Fabiszewski J. (ed.) - Przyroda Dolnego Śląska. Polska Akademia Nauk, Wrocław, 229-241 (in Polish).

PIN C., MIERZEJEWSKI M.P., DUTHOU J.L., 1987: Isochronous age Rb/Sr of Karkonosze granite from the quarry Szklarska Poręba Huta and significance of initial ${ }^{87} \mathrm{Sr} / 86 \mathrm{Sr}$ in this granite. Przegląd Geologiczny 10, 512-517 (in Polish with English abstract).

RAMDOHR P., 1969: The ore minerals and their intergrowths. Pergamon Press, 1174 pp.

SCOTT S.D., 1983: Chemical behaviour of sphalerite and arsenopyrite in hydrothermal and metamorphic environments. Mineralogical Magazin 47, 427-435.

SHARP Z.D., ESSENE E.J., KELLY W., 1985: Reexamination of the arsenopyrite geothermometer: pressure considerations and applications to natural assemblages. Canadian Mineralogist 23, 517-534.

TOULMIN P., BARTON P.B., 1964: A thermodynamic study of pyrite and pyrrhotite. Geochimica et Cosmochimica Acta 28, 641-671.

TRAUBE H., 1888: Die Minerale Schlesiens. J.U. Kern ěs Verlag. Breslau, 275 pp.

WINKLER H.G.F., 1979: Petrogenesis of metamorphic rocks, $5^{\text {th }}$ edn. Springer-Verlag, New York-Heidelberg-Berlin, $348 \mathrm{pp}$. 
WISZNIEWSKA J., 1984: The genesis of ore-mineralization of the Izera Schists in the Kamienica Range (Sudetes). Archiwum Mineralogiczne XL, 115-187 (in Polish with English abstract).

ŻELAŹNIEWICZ A., NOWAK I., ACHRAMOWICZ S., CZAPLIŃSKI W., 2003: The northern part of the Izera-Karkonosze Block: a passive margin of the Saxothuringian terrane. In: Ciężkowski W., Wojewoda J., Żelaźniewicz A. (eds) - Sudety Zachodnie: od wendu do czwartorzędu, 17-32, WIND, Wrocław (in Polish with English abstract).

Ksenia MOCHNACKA, Teresa OBERC-DZIEDZIC, Wojciech MAYER, Adam PIECZKA, Michat GORALSKI

\section{Wystąpienie siarczków w Sowiej Dolinie koło Karpacza - przykład mineralizacji kruszcowej w aureoli kontaktowej granitu Karkonoszy (Sudety, Polska)}

\section{Streszczenie}

Hornfelsy Sowiej Doliny należą do jednostki izersko-kowarskiej i są częścią serii łupkowej grupy Velkej Úpy, przeobrażonej na kontakcie z waryscyjskim granitem Karkonoszy. W Sowiej Dolinie istnieją ślady dawnych robót górniczych, wyloty sztolni i hałdy, na których znaleźć można okazy z mineralizacją siarczkową. Okruszcowane hornfelsy odznaczają się dobrze zachowaną foliacją i lineacją. Przejawem metamorfizmu kontaktowego są poligonalne zarysy ziaren kwarcu oraz rozpad muskowitu na sillimanit, zgodnie z reakcją: muskowit + kwarc $=\mathrm{Al}_{2} \mathrm{SiO}_{5}+\mathrm{K}$-skaleń $+\mathrm{H}_{2} \mathrm{O}$, która oznacza warunki metamorfizmu wysokiego stopnia i osiągnięcie temperatury powyżej $600^{\circ} \mathrm{C}$, a także krystalizacja andaluzytu i kordierytu, całkowicie zamienionego w pinit. Efektem zmian kontaktowych jest również powstanie pseudomorfoz po granacie.

Najbogatsze skupienia minerałów kruszcowych stwierdzone zostały w hornfelsach wzbogaconych w kwarc lub przecinanych żyłkami kwarcowo-skaleniowymi.

Dominującym minerałem rudnym jest pirotyn, rzadziej pojawia się piryt. Minerały te tworzą masywne skupienia kilkucentymetrowej miąższości, niekiedy także żyłki lub struktury rozproszone. $\mathrm{W}$ mniejszych ilościach występują: chalkopiryt, galena, sfaleryt, arsenopiryt, bornit, markasyt oraz minerały Ti.

Sukcesja minerałów kruszcowych została określona na podstawie przerostów mineralnych (tab. 2). Najstarsze minerały, ilmenit i rutyl, są związane przypuszczalnie z metamorfizmem regionalnym. Po minerałach Ti krystalizował pirotyn. Młodszy od niego jest chalkopiryt, którego starsza generacja tworzy zrosty z pirotynem, następna natomiast występuje jako odmieszania w sfalerycie. Po pirotynie i starszym chalkopirycie, $\mathrm{w}$ tym samym czasie powstawały sfaleryt, arsenopiryt i galena. Markasyt jest minerałem wtórnym, tworzącym się w początkowych stadiach procesu wietrzenia rud na hałdzie. 
Następstwo siarczków potwierdziła interpretacja geotermometryczna wyników analiz chemicznych $w$ mikroobszarze. Wykazała ona, że temperatury powstawania pirotynu wahały się $\mathrm{w}$ zakresie temperatur $630-265^{\circ} \mathrm{C}$, a arsenopiryt krystalizował w temperaturze około $390^{\circ} \mathrm{C}$.

Temperatury powstawania kwarcu żyłowego oznaczone za pomocą inkluzji ciekło-gazowych mieszczą się $\mathrm{w}$ zakresie temperatur $380-150^{\circ} \mathrm{C}$.

Porównanie obserwacji mikroskopowych rud z danymi chemicznymi i petrologicznymi pozwala na sugestię, że procesy metamorfizmu kontaktowego $\mathrm{w}$ temperaturach około $600^{\circ} \mathrm{C}$ odpowiadają krystalizacji wysokotemperaturowego pirotynu, natomiast pozostałe siarczki i kwarc żyłowy tworzyły się w procesach hydrotermalnych niższych temperatur, aż do około $150^{\circ} \mathrm{C}$. 
